\title{
The Effect of Leadership and Religiosity on Motivation and Performance of Construction Labor in Sumenep Regency
}

\author{
Mohamad Harun ${ }^{1}$, Zaenal Fanani ${ }^{2}$, Sugiono ${ }^{3}$ \\ \{mohamadharun74@gmail.com ${ }^{1}$,prof_zaenalfanani@yahoo.co.id ${ }^{2}$,sugiono_ub@yahoo.com ${ }^{3}$ \} \\ Universitas Brawijaya, Indonesia ${ }^{1,2,3}$ \\ Universitas Wiraraja, Indonesia ${ }^{1}$
}

\begin{abstract}
Human resources are a very important and strategic part of other resources such as materials, money, methods and equipment in construction companies; this is due to the very dynamic human nature. In addition, if there is a lack of professional / competitive workers, construction service companies will not be able to carry out its activities optimally even though all other resources are available. Realizing the importance of the role of construction workers as human resources in the process of construction project activities, it is expected that the performance workers can be improved through a variety of ways so that they are able to work more productively and professionally. Many factors can be done to improve the performance of construction workers among others through leadership style, religiosity and motivation. The right leadership model can improve performance. This study aims to analyze and determine the effect of leadership and religiosity on the motivation and performance of construction workers. The research method used is Structural Equation Modeling (SEM) and using IBM AMOS software for processing data obtained through construction workers survey. Based on the results of data analysis, it is known that leadership style and religiosity have a significant effect on motivation and motivation has a significant effect on performance. While leadership has no effect on performance except through an intermediary motivation.
\end{abstract}

Keywords: Leadership, Religiosity, Motivation, Performance.

\section{Introduction}

The construction industry plays a major role in the development and achievement of community goals. Construction is one of the largest industries and contributes around $10 \%$ of gross national product in industrialized countries. The construction industry has complexity in nature because it contains a large number of parties involved, both as clients, contractors, consultants, stakeholders, shareholders and regulators. The performance of the construction industry is influenced by the national economy [1]. Construction is a major activity in economic activity, given its contribution to gross regional domestic product (GRDP). The construction industry, however, faces the problem of decreasing productivity levels and lack of productivity standards due to poor performance of construction workers. Increasing labor productivity has been a challenge in the construction industry so far. Construction workers contribute $30-50 \%$ of the total construction cost because construction workers form a large part of this. Then, the 
maximum performance or productivity of construction workers is an important factor that contributes to the success of development [2].

Leadership style is the leader behavior that someone uses when they want to influence others. There are four types of Path Goal leadership classifications, namely directive leadership style, supportive leadership style, participative leadership style, and task-oriented leadership style. Various leadership styles can be used by a leader to influence and motivate his subordinates, so as to improve the performance of his subordinates in doing work [3]. Leadership is a process where someone influences others to be subordinates in achieving common goals [4]. Indicators of leadership style that are often used in research are Leadership Directive, Supportive leadership and Participatory leadership

Religiosity is the religious attitude of an individual who has been deeply internalized and has become an inseparable part of himself. Individual religiosity is often interpreted as how deep the religious knowledge, how strong is the belief in religious values and dogmas, how intensely carrying out the worship recommended by religion and how deep the appreciation of the religious values they hold. In this study, the indicators of religiosity used are aspects of ideology, worship, appreciation, knowledge, practice [5].

Extrinsic motivation is behavior that is formed for needs related to material and social appreciation. Extrinsic motivation concerns lower level needs (lower level needs). Indicators of extrinsic motivation include wages, job security, job benefits, status and social contact [6]. According to Mangkunegara that "the notion of performance (work performance) is the work of quality and quantity achieved by an employee in carrying out their duties in accordance with the responsibilities given to him". Based on several theories that have been mentioned, the performance indicators used in this study are indicators of quantity, quality and time [7]. The Madurese are known as communities that hold strong Muslim identity. The determination is shown in their obedience in carrying out Islamic teachings to achieve the most noble and perfect life goals. The work ethic of Madurese who has been known to be very high because instinctively for them to work is part of their worship in accordance with the teachings of the religion (Islam) that they espouse [8]. Based on this phenomenon, this study aims to analyze and determine the effect of leadership and the level of religiosity on the motivation and performance of construction workers. The research analysis method used is Structual Equation Modeling (SEM) and uses IBM AMOS software to process data obtained through construction worker surveys.

\section{Research Methods}

\subsection{Collecting Data}

Primary data in this study are questions obtained through questionnaires about the influence of leadership style, religiosity and motivation on the performance of human resources construction projects. Secondary data collection in the form of data obtained from certain references or literature relating to factors of religiosity, leadership style, motivation and performance of human resources in the field of construction. Secondary data collection aims to obtain information and data on theories related to the subject matter obtained from various studies directly related to religiosity, leadership style and human resource performance of construction projects referred to through references from related research studies, final projects, 
theses, as well as scientific journals and literature and lecture materials from various universities related to the subject, internet media and other print media.

Data collection is done by questionnaire, using instruments that have been prepared. The object of research is something that is of concern and what is examined in research. The object of this research is the influence of leadership style, religiosity and motivation on the performance of human resources construction projects in Sumenep Regency. This study uses SEM (Structural Equation Model) analysis which is based on an evaluation of the interdependence relationship between variables. The results of the analysis are interpreted and the final step is concluded and given advice [9].

\subsection{Data Analysis}

The analytical method used in this study uses Structural Equation Modeling (SEM). SEM is a multivariate technique that combines aspects of multiple regression and factor analysis to estimate a series of simultaneous dependency relationships. After the model is declared fit or statistically accepted, the next step is to test the hypothesis with the help of IBM SPSS AMOS by analyzing the relationship between latent variables. The SEM is more flexible and comprehensive than any other approaches such as correlation, multiple regression, and ANOVA [10].

\subsection{Variables and Indicators}

Based on theoretical studies and the results of previous studies, the variables in this study require leadership, religiosity, motivation and performance. While the indicators of each of these variables are show in table 1.

Table 1. Variables and Research Indicators

\begin{tabular}{|c|c|c|c|}
\hline Variable & Symbol & Indicator & Symbol \\
\hline \multirow[t]{3}{*}{ Leadership } & \multirow[t]{3}{*}{ X1 } & Directive & $\mathrm{X} 11$ \\
\hline & & Supportive & $\mathrm{X} 12$ \\
\hline & & Participative & $\mathrm{X} 13$ \\
\hline \multirow[t]{5}{*}{ Religiosity } & \multirow[t]{5}{*}{$\mathrm{X} 2$} & Ideology & $\mathrm{X} 21$ \\
\hline & & Ritual & $\mathrm{X} 22$ \\
\hline & & Experience & $\mathrm{X} 23$ \\
\hline & & Intellectual & $\mathrm{X} 24$ \\
\hline & & Consequential & $\mathrm{X} 25$ \\
\hline \multirow[t]{2}{*}{ Motivation } & \multirow[t]{2}{*}{ Y1 } & Intrinsic & Y11 \\
\hline & & Extrinsic & Y12 \\
\hline \multirow[t]{3}{*}{ Performance } & \multirow[t]{3}{*}{ Y2 } & Quantity & $\mathrm{Y} 21$ \\
\hline & & Quality & Y22 \\
\hline & & Time & Y23 \\
\hline
\end{tabular}




\section{Result and Discussion}

\subsection{Results of Validity and Reliability of Research Indicators}

The indicators of a variable are said to be valid if it has a loading factor of more than 0.70 and is called reliable if the value of construct reliability $\left(\rho_{\eta}\right)>0.70$ and AVE value is greater than 0.50. Leadership Style Variable (X1) shows that the loading factor of the indicator is more than 0.70 so that all indicators are said to have convergent valid as a measure of Leadership Style Variable (X1). While the construct reliability value was 0.926 and AVE value was 0.806 so that the construct reliability for the construct of the Leadership Style (X1) variable was very well fulfilled. Following is a table of results of the validity and reliability of research indicators for the Leadership Style variable (X1).

Table 2. The results of validity and reliability test of research indicators for Leadership Style Variables (X1)

\begin{tabular}{ccccc}
\hline \multirow{2}{*}{ Indicators } & \multicolumn{2}{c}{ Validity Test } & \multirow{2}{*}{ Construct Reliability $(\rho \pi)$} & \multirow{2}{*}{ AVE } \\
\cline { 2 - 3 } X 1.1 & Loading & Note & & \\
$\mathrm{X} 1.2$ & 0.861 & Valid & 0.926 & \multirow{2}{*}{0.806} \\
$\mathrm{X} 1.3$ & 0.889 & Valid & & \\
\hline
\end{tabular}

Religiosity Variable (X2) shows that the loading factor of the indicator is more than 0.70 so that all indicators are said to have convergent valid as a measure of Religiosity Variable (X2). While the value of construct reliability is 0.941 and AVE value is 0.765 so that the reliability of the constructs for the variable Religiosity (X2) is very well fulfilled. Following is a table of the results of the validity and reliability of research indicators for the Variability of Religiosity (X2).

Table 3. The results of validity and reliability of research indicators for Variable Religiosity (X2)

\begin{tabular}{ccccc}
\hline \multirow{2}{*}{ Indicators } & \multicolumn{2}{c}{ Validity Test } & \multirow{2}{*}{ Construct Reliability $(\rho \pi)$} & \multirow{2}{*}{ AVE } \\
\cline { 2 - 3 } & Loading & Note & & \\
X2.1 & 0.974 & Valid & & \\
X2.2 & 0.821 & Valid & 0.941 & 0.765 \\
X2.3 & 0.760 & Valid & & \\
X2.4 & 0.823 & Valid & & \\
X2.5 & 0.972 & Valid & & \\
\hline
\end{tabular}

Motivation Variable (Y1) shows that the loading factor of the indicator is more than 0.70 so that all indicators are said to have convergent valid as a measure of Motivation Variable (Y1). While the construct reliability value is 0.950 and AVE value is 0.904 so that the construct reliability for the Motivation Variable construct (Y1) is very well fulfilled. Here is a table of the results of the validity and reliability of research indicators for the Motivation Variable (Y1)

Table 4. The results of the validity and reliability test of research indicators for Motivational Variables (Y1)

\begin{tabular}{|c|c|c|c|c|}
\hline \multirow{2}{*}{ Indicators } & \multicolumn{2}{|c|}{ Validity Test } & \multirow{2}{*}{ Construct Reliability $(\rho \pi)$} & \multirow{2}{*}{ AVE } \\
\hline & Loading & Note & & \\
\hline Y1.1 & 0.921 & Valid & \multirow{2}{*}{0.950} & \multirow{2}{*}{0.904} \\
\hline Y1.2 & 0.980 & Valid & & \\
\hline
\end{tabular}


Performance Variable (Y2) indicates that the factor load of the indicator is more than 0.70 so that all indicator indicators have been approved as gauges as Performance Variables (Y2). While the reliability construct value is 0.926 and AVE value is 0.806 so that the construct reliability for the Performance Variable construct (Y2) is very well fulfilled. The following is a table of test results for validity and reliability of research indicators for Performance (Y2)

Table 5. The results of the validity and reliability test of research indicators for Performance Variables (Y2)

\begin{tabular}{|c|c|c|c|c|}
\hline \multirow{2}{*}{ Indicators } & \multicolumn{2}{|c|}{ Validity Test } & \multirow[b]{2}{*}{ Construct Reliability $(\rho \pi)$} & \multirow[b]{2}{*}{ AVE } \\
\hline & Loading & Information & & \\
\hline Y2.1 & 0.847 & Valid & \multirow{3}{*}{0.926} & \multirow{3}{*}{0.806} \\
\hline Y2.2 & 0.926 & Valid & & \\
\hline Y2.3 & 0.918 & Valid & & \\
\hline
\end{tabular}

\subsection{Fulfillment of Structural Equation Modeling (SEM) Assumptions}

Examination of data outliers is done by the Mahalanobis Distance method. If the Mahalanobis distance is significant $(\mathrm{p}<0.01)$, then the data is said to be outliers. The test was conducted simultaneously with SEM analysis using AMOS 18 software. The results of the examination using Mahalanobis distance showed that the observation data used in this study showed that there were no data samples that indicated outliers occurred.

The normality test aims to test whether in the regression model, the dependent variable and the independent variables both have normal distributions or not. A good regression model is to have a normal or near normal data distribution. SEM requires meeting the normality assumption. The easiest test is to observe the skewness value of the data used. The statistical value to test for normality is called the $\mathrm{Z}$-value. If $\mathrm{Z}$ value is greater than critical value, it can be assumed that the data distribution is not normal otherwise.

The theoretical value can be determined based on the level of significance desired. Data normality can be demonstrated by the presence of Critical Ratio (CR) with a threshold value of \pm 2.58 at a significance level of 0.01 or $1 \%$. Normality test of the data used in this study shows that the data is no value greater than \pm 2.58 . Thus, the data is normal.

\subsection{Results of Confirmatory Factor Analysis}

The loading factor resulting from the confirmatory factor analysis can be used to determine which indicator most strongly influences the latent variable. The indicator that produces the biggest loading factor is determined as the indicator that most strongly influences the latent variable in question. The full final confirmatory factor analysis results are presented in Appendix 3 in the SEM analysis results section. Following are the results of the final confirmatory factor analysis for the Leadership Style Variable (X1) Participatory indicator (X1.3) is the most powerful indicator influencing the variables of Leadership Style Variable (X1) while the weakest indicator influencing the Leadership Style Variable (X1) is indicator $\mathrm{X} 1.1$ which is a directive indicator. The indicator which most strongly influences the Variability of Religiosity (X2) is the ideological indicator (X2.1) while the weakest indicator influencing the Variability of Religiosity (X2) is the indicator X2.3 which is an experimental indicator. 
Table 6. The results of the final confirmatory factor analysis

\begin{tabular}{cccc}
\hline Indicator & Loading Factor & Indicator & Loading Factor \\
\hline $\mathrm{X} 1.1$ & 0.861 & Y1.1 & 0.921 \\
\hline $\mathrm{X} 1.2$ & 0.889 & $\mathrm{Y} 1.2$ & 0.980 \\
\hline $\mathrm{X} 1.3$ & 0.941 & $\mathrm{Y} 2.1$ & 0.847 \\
\hline $\mathrm{X} 2.1$ & 0.974 & $\mathrm{Y} 2.2$ & 0.926 \\
\hline $\mathrm{X} 2.2$ & 0.821 & $\mathrm{Y} 2.3$ & 0.918 \\
\hline $\mathrm{X} 2.3$ & 0.760 & & \\
\hline $\mathrm{X} 2.4$ & 0.972 & & \\
\hline $\mathrm{X} 2.5$ & 0.823 & & \\
\hline
\end{tabular}

The extrinsic motivation indicator (Y1.2) is the most powerful indicator influencing the Motivation Variable (Y1) while the weakest indicator influencing the Motivation Variable (Y1) is the intrinsic indicator (Y1.1). The strongest indicator influencing the Performance Variable (Y2) is the quality indicator (Y2.2) while the weakest indicator influencing the Performance Variable (Y2) is the quantity indicator (Y2.1)

\subsection{SEM Analysis Results}

The theoretical model in the conceptual framework of the study, said to be fit if it is supported by empirical data. To find out whether the hypothetical model is supported by empirical data or not, a goodness of fit overall model is tested.

Table 7. Result Test of Goodness of Fit Overall Model

\begin{tabular}{cccc}
\hline Goodness of Fit indeY & Cut off Value & Analysis Results & Model Evaluation \\
\hline$\chi^{2}$ - chi quare & $<$ df, $\alpha=0.05$ & 61.373 & Good Model \\
\hline Sig. & $\geq 0.05$ & 0.130 & Good Model \\
\hline RMSEA & $\leq 0.08$ & 0.047 & Good Model \\
\hline RMR & $\leq 0.10$ & 0.070 & Good Model \\
\hline GFI & $\geq 0.90$ & 0.938 & Good Model \\
\hline AGFI & $\geq 0.90$ & 0.965 & Good Model \\
\hline CMIN/ DF & $\leq 2.00$ & 2.448 & Marginal Model \\
\hline TLI & $\geq 0.90$ & 0.952 & Good Model \\
\hline CFI & $\geq 0.90$ & 0.963 & Good Model \\
\hline
\end{tabular}




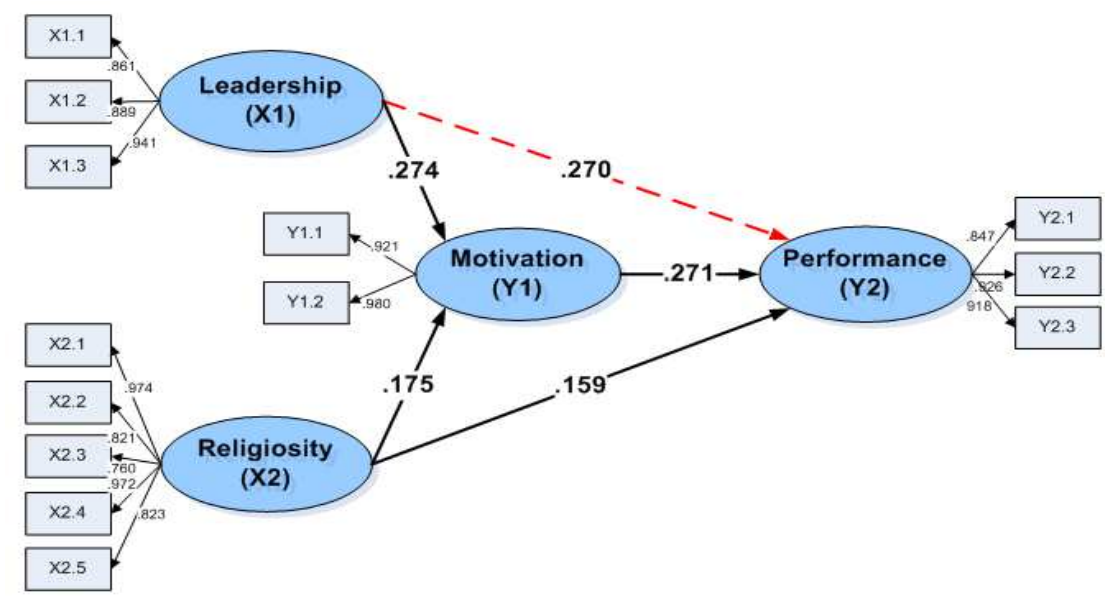

Fig. 1. Model and Result of SEM Analysis

\subsection{Hypothesis Testing Results}

Hypothesis testing of the study was carried out by t-test on each path of direct influence partially as presented in the table below.

Table 8. Result of Hypothesis testing

\begin{tabular}{|c|c|c|c|c|}
\hline \multirow{2}{*}{$\begin{array}{c}\text { Independent } \\
\text { Variable }\end{array}$} & \multirow{2}{*}{$\begin{array}{l}\text { Dependent } \\
\text { Variable }\end{array}$} & \multicolumn{3}{|c|}{ Path Coefficient Direct Effect } \\
\hline & & Std'ize & P-value & Note \\
\hline $\mathrm{H}_{1} \quad$ Leadership & Motivation & 0.231 & 0.000 & $\operatorname{sig} * * *$ \\
\hline $\mathrm{H}_{2}$ Religiosity & Motivation & 0.179 & 0.010 & $\operatorname{sig}^{* *}$ \\
\hline $\mathrm{H}_{3} \quad$ Leadership & Performance & 0.035 & 0.531 & non sig \\
\hline $\mathrm{H}_{4}$ Religiosity & Performance & 0.168 & 0.013 & $\operatorname{sig} * *$ \\
\hline $\mathrm{H}_{5}$ Motivation & Performance & 0.279 & 0.000 & Sig*** \\
\hline
\end{tabular}

Indirect effects are influences measured indirectly on one variable to another through intermediaries (intervening). The coefficient of indirect effect is obtained from the second product of the direct effect. If both coefficients of direct influence are significant. then the coefficient of indirect effects is also significant. However, if one or both of the coefficients of direct influence are non-significant. then the coefficient of indirect effect is non-significant. There are two indirect effects tested in this study are as the table below.

Table 9. Indirect Effect of Performance and Religiosity to Performance with an Intermediary Motivation

\begin{tabular}{llll} 
& \multicolumn{2}{c}{ with an Intermediary Motivation } & \\
\cline { 2 - 3 } \multicolumn{1}{c}{ Indirect Effect } & \multicolumn{2}{c}{ Test } & \multirow{2}{*}{ Conclusion } \\
\hline Leadership Style $\rightarrow$ & Leadership Style & Motivation $\rightarrow$ & \multirow{2}{*}{ Significant } \\
Performance & $\rightarrow$ Motivation & Performance & \\
with an intermediary & Coefficient: 0.274 & Coefficient: & \\
Motivation Coefficient & Significant & 0.271 & \\
$0.274 * 0.271=0.074$ & & Significant & \\
\hline
\end{tabular}




\begin{tabular}{lllll}
\hline Religiosity $\rightarrow$ Performance & Religiosity & $\rightarrow$ & Motivation \\
with an intermediary & Motivation & Performance & & Significant \\
Motivation & Coefficient: 0.175 & Coefficient: & & \\
Coefficient: $0.175 * 0.271=$ & Significant & 0.271 & \\
0.047 & & Significant & & \\
\hline
\end{tabular}

The hypothesis which states the leadership style is very significant on the motivation received. Standardized Path coefficient $=0.231$ with $p=0.000$ real results. This shows that the significant positive influence of Leadership Style on Motivation. This reflects how higher or better perceived leadership style makes motivation increasingly increasing. The hypothesis that religiosity has a significant effect on motivation is accepted. Standardization Path coefficient $=$ 0.179 with $p$ value $=0.010$ turned out to be significant. This illustrates that the significant positive effect of Religiosity on Motivation. This is in line with previous research which shows that leaders who are higher in extrinsic religious motivation towards personal gain are less likely than those who are lower in type of religious motivation to understand organizational values directed by others. However, neither intrinsic religious motivation nor extrinsic religious motivation towards social goals do not predict the tendency to understand organizational values directed by others [11].

While the hypothesis which states that the leadership style has a significant effect on performance is rejected. Standardization Path coefficient $=0.035$ with $\mathrm{p}$ value $=0.531$ apparently not significant. This illustrates that there is no significant influence of leadership style on performance. This illustrates that whether or not the leadership style does not affect performance. This is also in line with previous research which explains that transformational leadership has a significant direct effect on frustration and optimism, with the negative influence of frustration having a stronger effect on performance than the positive influence of optimism. Frustration and optimism are found to have a direct influence on performance, and emotions, frustration, and optimism, fully mediate the relationship between transformational leadership and performance [12].

The hypothesis that religiosity has a significant effect on performance is acceptable. Standardization Path coefficient $=0.168$ with $\mathrm{p}$ value 0.013 , it turns out significant. This illustrates that the significant positive effect of religiosity on performance. This shows that the better religiosity will be followed by increasing performance. Likewise, the hypothesis that motivation has a significant effect on performance is acceptable. Standardization Path coefficient $=0.279$ with $\mathrm{p}$ value $=0.000$ turned out to be significant. This illustrates that the significant positive effect of motivation on performance. This illustrates that the more perceived high or good motivation, the performance increases.

Besides the direct influence, based on the results of the analysis also found that the indirect effect between the leadership style on performance through an intermediary motivation obtained the coefficient of 0.074 . Thus, the indirect effect of leadership style on performance through motivational intermediaries is significant. This illustrates that motivation can be an intervening variable between leadership style on performance, so that the presence of motivation will make leadership style affect performance improvement. While the indirect effect between religiosity on performance through motivation intermediaries obtained the coefficient of 0.047 . Testing the indirect effect between religiosity on significant motivation and between motivation on significant performance, the indirect effect between Religiosity on Performance through motivational intermediaries is significant. This illustrates that the direct or indirect influence between religiosity on significant performance, so that it is still able to improve performance. 


\section{Conclusion}

Based on the results of the analysis and discussion, it can be concluded that the leadership style and the level of religiosity have a direct and significant effect on motivation. While motivation and religiosity also have a direct and significant effect on performance, except leadership style that has no influence on performance. While the indirect effect between leadership style and religiosity only occurs when the two variables are mediated by other variables, namely motivation. So, it can also be concluded that good religiosity and motivation will be able to improve performance, while the new leadership style can improve performance if there is also good motivation in it.

\section{References}

[1] R. Navon, "Automated project performance control of construction projects," Autom. Constr., vol. 14, no. 4, pp. 467-476, 2005.

[2] C. S. Okoro, I. Musonda, and J. Agumba, "Identifying Determinants of Construction Worker Performance on Construction Sites: A Literature Review," Int. J. Innov. Manag. Technol., vol. 8, no. 1 , pp. 60-63, 2017.

[3] S. P. Robbinson, "Perilaku Organisasi (Alih Bahasa, Benyamin, 2006) PenerČbit: PT Macanan Jaya Cemerlang." Jakarta-Indonesia, 2006.

[4] R. Kreitner and K. Angelo, "Orgnizational Behavior," Mc Graw-Hill Int., 2007.

[5] N. S. Dister, "Pengalaman dan motivasi beragama," Yogyakarta: Kanisius, 1988.

[6] G. R. Jones, Organizational theory: Text and cases. Prentice Hall, 2001.

[7] A. A. Mangkunegara and A. Prabu, "Manajemen Sumber Daya Manusia Perusahaan Bandung: PT Remaja Rosdakarya," 2000.

[8] H. de Jonge and E. Touwen-Bouwsma, Across Madura Strait: The Dynamics of an Insular Society. KITLV Press, 1995.

[9] Z. Awang, "A handbook on SEM for academicians and practitioners: the step by step practical guides for the beginners," Bandar Baru Bangi, MPWS Rich Resour., 2014.

[10] R. H. Hoyle, Structural equation modeling: Concepts, issues, and applications. Sage, 1995.

[11] N. E. Day and D. Hudson, "US small company leaders' religious motivation and other-directed organizational values," Int. J. Entrep. Behav. Res., 2011.

[12] J. R. McColl-Kennedy and R. D. Anderson, "Impact of leadership style and emotions on subordinate performance," Leadersh. Q., vol. 13, no. 5, pp. 545-559, 2002. 